\title{
Implementasi Data Mining Untuk Memprediksi Prestasi Siswa Berdasarkan Status Sosial Dan Kedisiplinan Pada Smk Bayu Pertiwi Menggunakan Metode Regresi Linier Berganda
}

\author{
Rudi Gunawan \\ Program Studi Sistem Informasi, STMIK Triguna Dharma
}

\begin{tabular}{l}
\hline Info Artikel \\
\hline Article history: \\
Received May $12^{\text {th }}, 2018$ \\
Revised June $15^{\text {th }}, 2018$ \\
Accepted Aug $05^{\text {th }}, 2018$
\end{tabular}

\section{Keyword:}

Data Mining

Prestasi Siswa

Regresi Linear Berganda

\begin{abstract}
ABSTRAK
Kemajuan suatu Sekolah salah satunya ditentukan dari banyaknya Siswa yang Mendaftar ke Sekolah untuk memperoleh pendidikan yang baik. Semakin meningkatnya jumlah tamatan siswa, maka semakin baik keberadaan Sekolah tersebut seperti yang disebutkan di atas bahwa salah satu faktor penting dalam Pendidikan adalah sumber daya manusia yang kompeten.

Dalam hal ini prediksi prestasi siswa sangat penting bagi suatu sekolah. Dimana dengan adanya Prediksi Prestasi siswa, sekolah dapat memberikan pelayanan pendidikan dengan kualitas yang baik terhadap siswa. Akan dirancang suatu aplikasi Data Mining menggunakan metode Regresi Linier Berganda untuk memprediksi Prestasi siswa Berdasarkan setatus sosial dan kedisiplinan pada Smk Bayu Pertiwi Menggunakan metode Regresi Linier Berganda Dari hasil perhitungan, Sekolah dapat meramalkan tingkat prestasi sesuai dengan prestasi untuk masa yang datang. Dengan metode Regresi Linier Berganda dapat membantu mempermudah analisa kumpulan data menjadi suatu hasil peramalan (prediksi) Tingkar Prestasi di sekolah tersebut.
\end{abstract}

Copyright (C) 2018 STMIK Triguna Dharma. All rights reserved.

\begin{tabular}{ll}
\hline First Author & \\
Nama & : Rudi Gunawan, SE, M,Si \\
Program Studi & : Sistem Informasi STMIK Triguna Dharma \\
E-Mail & : rudi_gunawan8899@yahoo.com
\end{tabular}

\section{PENDAHULUAN}

Pendidikan merupakan salah satu faktor kemajuan dan kemandirian bangsa. Dengan majunya pendidikan suatu bangsa, maka tercipta generasi penerus yang berkualitas. Pendidikan bertujuan untuk mengembangkan potensi peserta didik agar menjadi manusia yang beriman dan bertakwa kepada Tuhan Yang Maha Esa, berakhlaq mulia, sehat, berilmu, kreatif, mandiri dan menjadi warga negara yang demokratis serta bertanggungjawab. Berdasarkan tujuan pendidikan tersebut maka kualitas dan manajemen pembelajaran di sekolah atau lembaga pendidikan perlu ditingkatkan. Salah satu indikator kualitas dan manajemen sekolah atau lembaga pendidikan dapat dilihat dari prestasi belajar siswa.

Sekolah Menengah Kejuruan (SMK) merupakan lembaga pendidikan yang berupaya menciptakan siswa tamatan yang terampil dan memiliki keahlian sehingga lulusannya dapat langsung terjun ke dunia kerja maupun melanjutkan ke pendidikan yang lebih tinggi. Namun setiap siswa memiliki tingkat keterampilan yang berbeda sehingga memerlukan bimbingan yang berbeda pula. Untuk itu perlu diketahui lebih dini mengenai tingkat prestasi dan ketrampilan siswa agar

bisa memberikan pembelajaran dan bimbingan sesuai dengan kemampuan siswa tersebut. Yang harus dilakukan oleh lembaga pendidikan adalah melakukan antisipasi terhadap siswa yang berpotensi mengalami hambatan atau kurang berprestasi dalam belajarnya. Hal ini penting dilakukan karena semakin awal sekolah kejuruan mengetahui adanya potensi siswa yang kemungkinan akan mengalami hambatan dalam belajarnya, maka sekolah bisa melakukan langkah-langkah antisipasi. 
Faktor status sosial orang tua yang mewujudkan pada kemampuan finansialnya. Kemampuan finansial yang berbeda-beda sedikit banyak akan berpengaruh terhadap prestasi belajar siswa. Dengan kemampuan finansial orang tua, tentunya akan mempengaruhi fasilitas belajar yang disediakan oleh orang tua terhadap sarana dan prasarana yang dibutuhkan oleh seorang siswa untuk meningkatkan prestasi belajarnya. Dalam melakukan prediksi prestasi siswa Berdasrkan Social Ekonomi Dan Kedisplinan tidaklah mudah dan membutuhkan waktu yang lama serta memerlukan beberapa metode atau teknik dalam menyelesaikanya, dalam hal ini bidang ke ilmuan yang digunakan adalah Data Mining dan metode yang digunakan adalah Regresi Linier Berganda.

Regresi Linier Berganda adalah hubungan secra linier antara dua atau lebih variabel independen $(\mathrm{X} 1, \mathrm{X} 2, \ldots \mathrm{Xn})$ dengan variabel $(\mathrm{Y})$. Analisis untuk mengetahui arah hubungan antara variabel independen dengan variabel dependen.

\section{LANDASAN TEORITIS}

\subsection{Data Mining}

Menurut Turban data mining adalah suatu istilah yang digunakan untuk menguraikan penemuan pengetahuan di dalam database. Data mining adalah proses yang menggunakan statistika, matematika, kecerdasan buatan, dan machine learning untuk mengekstraksi dan mengidentifikasi informasi yang bermanfaat dan pengetahuan yang terakit dari berbagai database besar

Menurut Gartner Group dalam Data mining adalah suatu proses menentukan hubungan yang berarti pola, dan kecenderungan dengan memeriksa dalam sekumpulan besar data yang tersimpan dalam penyimpanan dengan menggunakan teknik pengenalan pola seperti teknik statistik dan matematika.

Menurut pramudino dalam Kusrin, (2009:6). Data mining bukanlah suatu bidang yang sama sekali baru.salah satu kesulitan untuk mendefenisikan data mining adalah kenyataan bahwa data mining mewarisi banyak aspek dan teknik dari bidang-bidang ilmu yang sudah mapan terlebih dulu.gambar 2.1 menunjukan bahwa data mining memiliki akar yang panjang dari bidang ilmu seperti kecerdasan buatan (artificial intelligent), machine learning, statistic, database, dan juga information retrieval.

Menurut Fayyad data mining dan knowledge discovery in database(KDD) sering kali digunakan secara bergantian untuk menjelaskan proses penggalian informasi tersembunyi dalam suatu basis data yang besar. Sebenarnya kedua istilah tersebut memiliki istilah yang berbeda, tetapi berkaitan satu sama lain. Dan salahsatu tahapan dalam keseluruhan proses KDD adalah data mining.

\subsection{Regresi Linear Berganda}

Regresi dalam pengertian moderen menurut Gujarati (2009) ialah sebagai kajian terhadap ketergantungan satu variabel, yaitu variabel tergantung terhadap satu atau lebih variabel lainnya atau yang disebut sebagai variabel-variabel eksplanatori dengan tujuan untuk membuat estimasi dan/atau memprediksi rata-rata populasi atau nilai rata-rata variabel tergantung dalam kaitannya dengan nilai-nilai yang sudah diketahui dari variabel ekslanatorinya. Regresi linier mempunyai persamaan yang disebut sebagai persamaan regresi. Persamaan regresi mengekspresikan hubungan linier antara variabel tergantung/variabel kriteria yang diberi simbol Y dan salah satu atau lebih variabel bebas/prediktor yang diberi simbol X jika hanya ada satu prediktor dan X1, X2 sampai dengan Xk, jika terdapat lebih dari satu predictor

Regresi Linier Berganda adalah hubungan secra linier antara dua atau lebih variabel independen $\left(\mathrm{X}_{1,}, \mathrm{X}_{2, \ldots}, \mathrm{Xn}\right)$ dengan variabel $(\mathrm{Y})$. Analisis untuk mengetahui arah hubungan antara variabel independen dengan variabel dependen.

J.Supranto(2009:239) menjelaskan untuk memperkirakan/meramalkan nilai variabel Y,akan lebih baik apa bila kita ikut memperhitungkan variabel-variabel lain yang ikut mempengaruhi $Y$. Dengan demikian kita mempunyai hubungan antara satu variabel yang tidak bebas (dependent variable) $Y$ dengan beberapa variabel lain yang bebas (independent variable) $X_{1}, X_{2}, \ldots X_{K}$

Missalnya $Y=$ hasil penjualan, akan dipengaruhi oleh daya beli $\left(X_{1}\right), \operatorname{harga}\left(X_{2}\right.$ ) import $\left(X_{3}\right)$ dan lain sebgainya; $Y=$ prosuksi padi, akan di pengaruhi oleh $X_{1}=$ bibit, $X_{2}=$ pupuk, $X_{3}=$ curah hujan $X_{4}=$ luas sawah,dan lain sebagainya,

Untuk meramalkan Y apa bila semua variabel bebas diketahui, maka kita dapat menggunakan persamaan regresi linier berganda. Hubungan $\mathrm{Y}$ dan $X_{1} X_{2} \ldots, X_{k}$ yang sebenarnya adalah sebagai berikut.

$y_{i}=B_{0}+B_{1} X_{1 i}+B_{2} X_{2 i}+\cdots+B_{k} X_{k i}+E_{i}$ (untuk popolasi)

$y_{i}=b_{0}+b_{1} X_{1 i}+b_{2} X_{2 i}+\cdots+b_{k} X_{k i}+e_{i}$ (untuk sampel) 
3. ANALISIS DAN HASIL

Tabel 3.1 Data Orang Tua Siswa

\begin{tabular}{|c|l|l|l|c|c|}
\hline NO & \multicolumn{1}{|c|}{ Nama Siswa } & \multicolumn{1}{|c|}{ Alamat } & Orang Tua Siswa & Gaji/Bulan & $\begin{array}{c}\text { Jumlah } \\
\text { Anak }\end{array}$ \\
\hline 1 & Abdan M. Haq & JL.Kenduri dsn VII & Suryono & 1.500 .000 & 2 \\
\hline 2 & Abdilah & $\begin{array}{l}\text { Dusun II Gg.Abadi } \\
\text { No.226 }\end{array}$ & M.Taufiq & 3.000 .000 & 4 \\
\hline 3 & Ahmad Afandi & Dusun.VI Sridadi, Sei & Hadi & 4.500 .000 & 4 \\
\hline 4 & Beni Andika & Dusun. II Sidodadi & Wakiran & 2.400 .000 & 3 \\
\hline 5 & Danar Evasari & $\begin{array}{l}\text { Sei Semayang Jln. Jati } \\
\text { Pasar.IV }\end{array}$ & Musalih & 5.000 .000 & 4 \\
\hline 6 & Dina Saharada & Dusun. I Aman Damai & Julianto & 3.000 .000 & 3 \\
\hline 7 & Dodi Hendrawan & Dusun. VII Pulorejo & Wagirin & 3.500 .000 & 2 \\
\hline 8 & Francisco. S & Dusun.V Seimencirim & Siswoyo & 1.500 .000 & 2 \\
\hline 9 & Fani sundari & $\begin{array}{l}\text { Jln. Kenduri Dusun. } \\
\text { VII }\end{array}$ & Muhamad Jais & 2.950 .000 & 2 \\
\hline 10 & Indri susanti & $\begin{array}{l}\text { Dusun. II Gg. Abadi } \\
\text { No. 226 }\end{array}$ & Tatang surya & 2.800 .000 & 4 \\
\hline
\end{tabular}

Tabel 3.2 Data Rekap Absensi Siswa

\begin{tabular}{|c|l|c|c|c|c|c|}
\hline NO & \multicolumn{1}{|c|}{ NAMA } & I & S & A & TOTAL KEHADIRAN & $\begin{array}{c}\text { PERSENTASI } \\
\text { KEHADIRAN }\end{array}$ \\
\hline 1 & Abdan M. Haq & 0 & 0 & 0 & 300 & $100 \%$ \\
\hline 2 & Abdilah & 8 & 4 & 6 & 282 & $94 \%$ \\
\hline 3 & Ahmad Afandi & 2 & 5 & 0 & 293 & $98 \%$ \\
\hline 4 & Beni Andika & 0 & 0 & 0 & 300 & $100 \%$ \\
\hline 5 & Danar Evasari & 0 & 0 & 0 & 300 & $100 \%$ \\
\hline 6 & Dina Saharada & 6 & 8 & 4 & 282 & $94 \%$ \\
\hline 7 & Dodi Hendrawan & 0 & 0 & 0 & 300 & $100 \%$ \\
\hline 8 & Francisco. S & 0 & 0 & 0 & 300 & $95 \%$ \\
\hline 9 & Fani Sundari & 7 & 2 & 7 & 284 & $97 \%$ \\
\hline 10 & Indri Susanti & 5 & 5 & 0 & 290 & \\
\hline
\end{tabular}

Ket:

$\mathrm{I}=\mathrm{izin}$

$\mathrm{S}=$ Sakit

$\mathrm{A}=$ Absen 
Tabel 3.3 Data Niilai Siswa

\begin{tabular}{|l|c|c|c|c|c|}
\hline \multicolumn{1}{|c|}{ NAMA } & $\begin{array}{c}\text { PERBAIKAN } \\
\text { PC }\end{array}$ & $\begin{array}{c}\text { PERAWATAN } \\
\text { PERIFERAL }\end{array}$ & LAN & OFICE & ELEKTRO \\
\hline Abdan M. Haq & 100 & 100 & 100 & 100 & 98 \\
\hline Abdilah & 90 & 90 & 85 & 95 & 89 \\
\hline Ahmad Afandi & 80 & 70 & 81 & 90 & 81 \\
\hline Beni Andika & 80 & 100 & 100 & 100 & 100 \\
\hline Danar Evasari & 81 & 75 & 60 & 75 & 86 \\
\hline Dina Saharada & 90 & 70 & 85 & 90 & 71 \\
\hline Dodi Hendrawan & 88 & 87 & 94 & 80 & 91 \\
\hline Francisco. S & 60 & 60 & 59 & 60 & 60 \\
\hline Fani Sundari & 100 & 60 & 60 & 60 & 60 \\
\hline Indri Susanti & 79 & 80 & 69 & 70 & 68 \\
\hline
\end{tabular}

Tabel 3.4 Data Nilai Siswa (Lanjutan)

\begin{tabular}{|c|c|c|c|c|c|c|c|}
\hline $\begin{array}{c}\text { Bahasa } \\
\text { Inggris }\end{array}$ & $\begin{array}{c}\text { Bahasa } \\
\text { Francis }\end{array}$ & $\begin{array}{c}\text { Seni } \\
\text { Budaya }\end{array}$ & Fisika & Olahraga & $\begin{array}{c}\text { Html } \\
\text { Dasar }\end{array}$ & Matematika & Total \\
\hline 90 & 100 & 100 & 100 & 100 & 100 & 90 & 1178 \\
\hline 95 & 90 & 90 & 90 & 100 & 100 & 90 & 1104 \\
\hline 79 & 83 & 97 & 88 & 90 & 60 & 81 & 980 \\
\hline 90 & 100 & 97 & 99 & 100 & 100 & 100 & 1166 \\
\hline 75 & 70 & 75 & 90 & 65 & 77 & 60 & 889 \\
\hline 69 & 69 & 72 & 58 & 70 & 60 & 59 & 863 \\
\hline 100 & 92 & 97 & 88 & 100 & 96 & 87 & 7100 \\
\hline 60 & 60 & 57 & 60 & 58 & 60 & 58 & 720 \\
\hline 60 & 60 & 60 & 60 & 60 & 60 & 60 & 964 \\
\hline 85 & 75 & 90 & 100 & 80 & 90 & 78 & 712 \\
\hline
\end{tabular}

Tabel 3.5 Data Keseluruhan

\begin{tabular}{|c|c|l|c|c|c|}
\hline NO & NISN & NAMA SISWA & $\begin{array}{c}\text { PENGHASILAN } \\
\text { ORANG } \\
\text { TUA/BULAN }\end{array}$ & $\begin{array}{c}\text { PERSENTASI } \\
\text { KEHADIRAN } \\
\text { SISWA }\end{array}$ & $\begin{array}{c}\text { Prestasi } \\
\text { (Total Nilai } \\
\text { Akhir) Dari } \\
\text { 12 MATPEL }\end{array}$ \\
\hline 1 & 0011950038 & Abdan M. Haq & 1.500 .000 & $100 \%$ & 1178 \\
\hline 2 & 0017956130 & Abdilah & 3.000 .000 & $94 \%$ & 1104 \\
\hline 3 & 0008284464 & Ahmad Afandi & 4.500 .000 & $98 \%$ & 980 \\
\hline 4 & 0017262612 & Beni Andika & 2.400 .000 & $100 \%$ & 1166 \\
\hline 5 & 0015055528 & Danar Evasari & 5.000 .000 & $100 \%$ & 889 \\
\hline 6 & 0001868609 & Dina Saharada & 3.000 .000 & $94 \%$ & 863 \\
\hline 7 & 0005855998 & Dodi Hendrawan & 3.500 .000 & $100 \%$ & 1100 \\
\hline 8 & 0016713206 & Francisco. S & 1.500 .000 & $100 \%$ & 712 \\
\hline 9 & 0011950104 & Fani Sundari & 2.950 .000 & $95 \%$ & 720 \\
\hline 10 & 0015851751 & Indri Susanti & 2.800 .000 & $97 \%$ & 964 \\
\hline
\end{tabular}


Adapun langkah-langkah dalam melakukan pemodelan untuk algoritma Multiple Regression yaitu melakukan inisialisasi terhadap data siswa, normalisasi data, menghitung nilai sigma dari setiap variabel, mencari persamaan regresi.Pada bagian ini penulis akan mengolah data pemenuhan tenaga kerja dengan metode Multiple Regression sesuai dengan langkah-langkah yang telah dijelaskan sebelumnya.

1. Inisialisasi data kedalam variabel $\mathrm{X} 1, \mathrm{X} 2$ dan $\mathrm{Y}$

$\mathrm{X} 1$ dan X2 merupakan variabel bebas sedangkan Y merupakan variabel terikat yang dipengaruhi oleh X1 dan X2. Karena dianggap "Status Sosial" dan "Kedisiplinan" mempengaruhi jumlah "Prestasi Siswa" maka diinisialisaikan:
$\mathrm{X} 1=$ Status Sosial
X2 $=$ Kedisiplinan
$\mathrm{Y} \quad=$ Nilai Siswa

Tabel 3.6 Inisialisasi Data

\begin{tabular}{|l|c|c|c|}
\hline \multicolumn{1}{|c|}{ Nama Siswa } & X1 & X2 & Y \\
\hline Abdan M. Haq & 1.500 .000 & $100 \%$ & 1178 \\
\hline Abdilah & 3.000 .000 & $94 \%$ & 1104 \\
\hline Ahmad Afandi & 4.500 .000 & $98 \%$ & 980 \\
\hline Beni Andika & 2.400 .000 & $100 \%$ & 1166 \\
\hline Danar Evasari & 5.000 .000 & $100 \%$ & 889 \\
\hline Dina Saharada & 3.000 .000 & $94 \%$ & 863 \\
\hline Dodi Hendrawan & 3.500 .000 & $100 \%$ & 1100 \\
\hline Francisco. S & 1.500 .000 & $100 \%$ & 712 \\
\hline Fani Sundari & 2.950 .000 & $95 \%$ & 720 \\
\hline Indri Susanti & 2.800 .000 & $97 \%$ & 964 \\
\hline
\end{tabular}

2. Menormalisasikan data

Normalisasi data ditujukan untuk memudahkan proses perhitungan. Berikut adalah hasil normalisasi data dengan membagi variabel X1 dengan nilai 1000000, menjadikan nilai persentasi pada X2 menjadi nilai pecahan dan membagi nilai Y dengan nilai 1000.

Tabel 3.7 Normalisasi Data

\begin{tabular}{|l|c|c|c|}
\hline \multicolumn{1}{|c|}{ Nama } & X1 & X2 & Y \\
\hline Abdan M. Haq & 1.5 & 1 & 1.178 \\
\hline Abdilah & 3 & 0.94 & 1.104 \\
\hline Ahmad afandi & 4.5 & 0.98 & 0.98 \\
\hline Beni andika & 2.4 & 1 & 1.166 \\
\hline Danar evasari & 5 & 1 & 0.889 \\
\hline Dina saharada & 3 & 0.94 & 0.863 \\
\hline Dodi hendrawan & 3.5 & 1 & 1.1 \\
\hline Francisco. S & 1.5 & 1 & 0.712 \\
\hline Fani sundari & 2.95 & 0.95 & 0.72 \\
\hline Indri susanti & 2.8 & 0.97 & 0.964 \\
\hline
\end{tabular}

Mencari nilai $\sum \mathrm{X}_{1}, \sum \mathrm{X}_{2}, \sum \mathrm{Y}, \sum \mathrm{X}_{1}^{2}, \sum \mathrm{X}_{2}^{2}, \sum \mathrm{Y}^{2}, \sum \mathrm{X}_{1} \mathrm{X}_{2}, \sum \mathrm{X}_{1} \mathrm{Y}$, dan $\sum \mathrm{X}_{2} \mathrm{Y}$

Tabel 3.8 Tabel Penghitungan Nilai Sigma :

\begin{tabular}{|l|c|c|c|c|c|c|}
\hline \multicolumn{1}{|c|}{ Nama } & $\mathrm{X}_{1}$ & $\mathrm{X}_{2}$ & $\mathrm{Y}$ & $\mathrm{X}_{1}{ }^{2}$ & $\mathrm{X}_{2}{ }^{2}$ & $\mathrm{Y}^{2}$ \\
\hline Abdan M. Haq & 1.5 & 1 & 1.178 & 2.25 & 1 & 1.3877 \\
\hline Abdilah & 3 & 0.94 & 1.104 & 9 & 0.8836 & 1.2188 \\
\hline Ahmad afandi & 4.5 & 0.98 & 0.98 & 20.25 & 0.9604 & 0.9604 \\
\hline
\end{tabular}




\begin{tabular}{|l|c|c|c|c|c|c|}
\hline Beni andika & 2.4 & 1 & 1.166 & 5.76 & 1 & 1.3596 \\
\hline Danar evasari & 5 & 1 & 0.889 & 25 & 1 & 0.7903 \\
\hline Dina saharada & 3 & 0.94 & 0.863 & 9 & 0.8836 & 0.7448 \\
\hline Dodi hendrawan & 3.5 & 1 & 1.1 & 12.25 & 1 & 1.2100 \\
\hline Francisco. S & 1.5 & 1 & 0.712 & 2.25 & 1 & 0.5069 \\
\hline Fani sundari & 2.95 & 0.95 & 0.72 & 8.7025 & 0.9025 & 0.5184 \\
\hline Indri susanti & 2.8 & 0.97 & 0.964 & 7.84 & 0.9409 & 0.9293 \\
\hline$\sum$ & 30.15 & 9.78 & 9.676 & 102.3025 & 9.571 & 9.626 \\
\hline
\end{tabular}

Tabel 3.9 Tabel Penghitungan Nilai Sigma (Lanjutan) :

\begin{tabular}{|l|c|c|c|}
\hline \multicolumn{1}{c|}{ Nama } & $\mathrm{X}_{1} \mathrm{X}_{2}$ & $\mathrm{X}_{1} \mathrm{Y}$ & $\mathrm{X}_{2} \mathrm{Y}$ \\
\hline Abdan M. Haq & 1.5 & 1.767 & 1.178 \\
\hline Abdilah & 2.82 & 3.312 & 1.03776 \\
\hline Ahmad afandi & 4.41 & 4.41 & 0.9604 \\
\hline Beni andika & 2.4 & 2.7984 & 1.166 \\
\hline Danar evasari & 5 & 4.445 & 0.889 \\
\hline Dina saharada & 2.82 & 2.589 & 0.81122 \\
\hline Dodi hendrawan & 3.5 & 3.85 & 1.1 \\
\hline Francisco. S & 1.5 & 1.068 & 0.712 \\
\hline Fani sundari & 2.8 & 2.124 & 0.684 \\
\hline Indri susanti & 2.72 & 2.6992 & 0.93508 \\
\hline$\sum$ & 29.5 & 29.0626 & 9.47346 \\
\hline
\end{tabular}

Dari tabel diatas maka diketahui nilai :

$\begin{array}{lll}\sum \mathrm{X}_{1} & = & 30.15 \\ \sum \mathrm{X}_{2} & = & 9.78 \\ \sum \mathrm{Y}= & 9.676 & \\ \sum \mathrm{X}_{1}{ }^{2} & = & 102.3025 \\ \sum \mathrm{X}_{2}^{2} & = & 9.571 \\ \sum \mathrm{Y}^{2} & = & 9.626 \\ \sum \mathrm{X}_{1} \mathrm{X}_{2} & = & 29.5 \\ \sum \mathrm{X}_{1} \mathrm{Y} & = & 29.0626 \\ \sum \mathrm{X}_{2} \mathrm{Y} & = & 9.47346\end{array}$

Menghitung nilai $\sum \mathrm{x}_{1}{ }^{2}, \sum \mathrm{x}_{2}{ }^{2}, \sum \mathrm{y}^{2}, \sum \mathrm{x}_{1} \mathrm{x}_{2}, \sum \mathrm{x}_{1} \mathrm{y}$, dan $\sum \mathrm{x}_{2} \mathrm{y}$

$\sum \mathrm{x}_{1}{ }^{2} \quad=102.3025-\frac{(30.15)^{2}}{10}=11.40025$

$\sum \mathrm{x}_{2}{ }^{2} \quad=9.571-\frac{(9.78)^{2}}{10}=0.006160$

$\sum \mathrm{x}_{1} \mathrm{x}_{2}=29.5-\frac{(102.3025)}{10}=-0.0182$

$\sum \mathrm{x}_{1} \mathrm{y} \quad=29.0626-\frac{(27.8 \times 9.064)}{10}=0.84172$

$\sum \mathrm{x}_{2} \mathrm{y} \quad=9.47346-\frac{(8.128744 \mathrm{x} 9.064)}{10}=0.148497$

3. Penghitungan nilai $\mathrm{a}, \mathrm{b} 1 \mathrm{dan} \mathrm{b} 2$

$\mathrm{b}_{1}=\frac{(0.150682)(0.84172)-(0.148497) 0.57204)}{(8.056)(0.150682)-(0.57204)^{2}}=0.04724$

Dari nilai b1 dapat diketahui nilai untuk variabel X1 berbanding positif, artinya jika status sosial atau pendapatan orang tua meningkat maka terjadi peningkatan pada prestasi siswa.

$\mathrm{b}_{2}=\frac{(10.076)(-17.7862)-(0.46812)(-0.055)}{(8.056)(0.150682)-(0.57204)^{2}}=0.806162$ 
Dari nilai b2 dapat diketahui nilai untuk variabel X2 berbanding positif, artinya jika kedisiplinan siswa meningkat maka terjadi peningkatan pada prestasi siswa.

$\mathrm{a}=\frac{(9.676)-(27.8 \times(0.04724))-(8.932 *(0.806162))}{10}=0.11621$

4. Pencarian persamaan regresi

Karena nilai a, b1 dan b2 telah diperoleh, maka persamaan regresinya adalah :

$\mathrm{Y}=\mathrm{a}+\mathrm{b}_{1} \mathrm{X}_{1}+\mathrm{b}_{2} \mathrm{X}_{2}$

$\mathrm{Y}=0.11621+\left(0.04724 \mathrm{X}_{1}\right)+\left(0.806162 \mathrm{X}_{2}\right)$

Persamaan berikut merupakan persamaan yang akan digunakan untuk mencari nilai estimasi dari nilai duga yang ada.

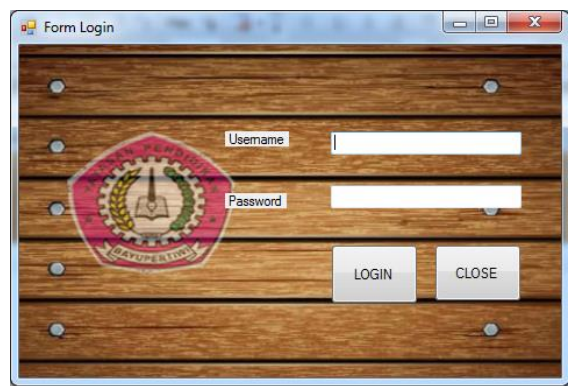

Gambar 5.1 Tampilan Form Menu Login

Menu utama merupakan tampilan yang akan muncul setelah admin melakukan login pada aplikasi Implementasi Data Mining Untuk Memprediksi Prestasi Siswa Berdasarkan Status Sosial Dan Kedisiplinan Pada SMK Bayu Pertiwi Menggunakan Metode Regresi linier Berganda.

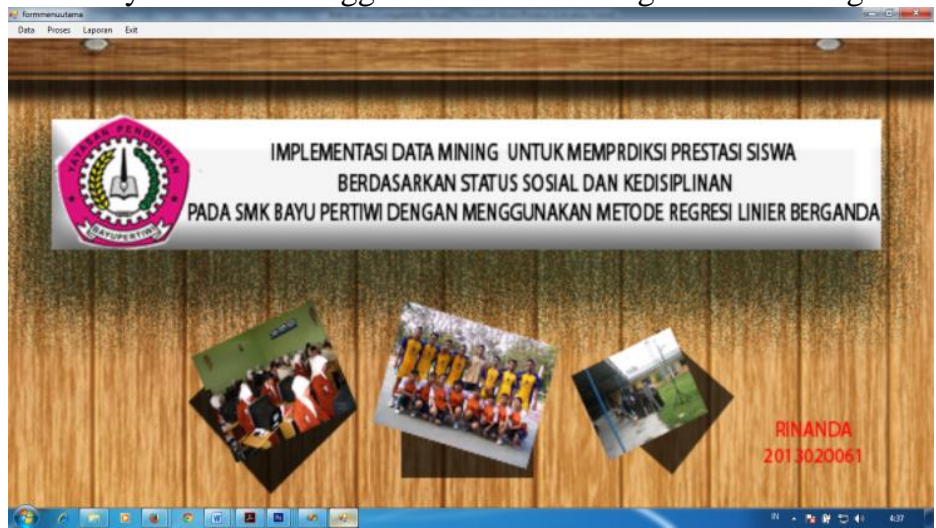

Gambar 5.2 Tampilan Form Menu Utama

Menu utama terdiri atas menu input data, menu proses, menu laporan dan menu keluar. Di dalam menu input data terdapat sub menu seperti sub menu input data siswa, input hitung persamaan regresi, input proses, Menu laporan terdapat laporan data siswa menu laporan prediksi . Sedangkan menu keluar terdapat sub menu keluar.

Form data Siswa merupakan tampilan yang digunakan admin untuk mengumpulkan data siswa pada aplikasi ini.

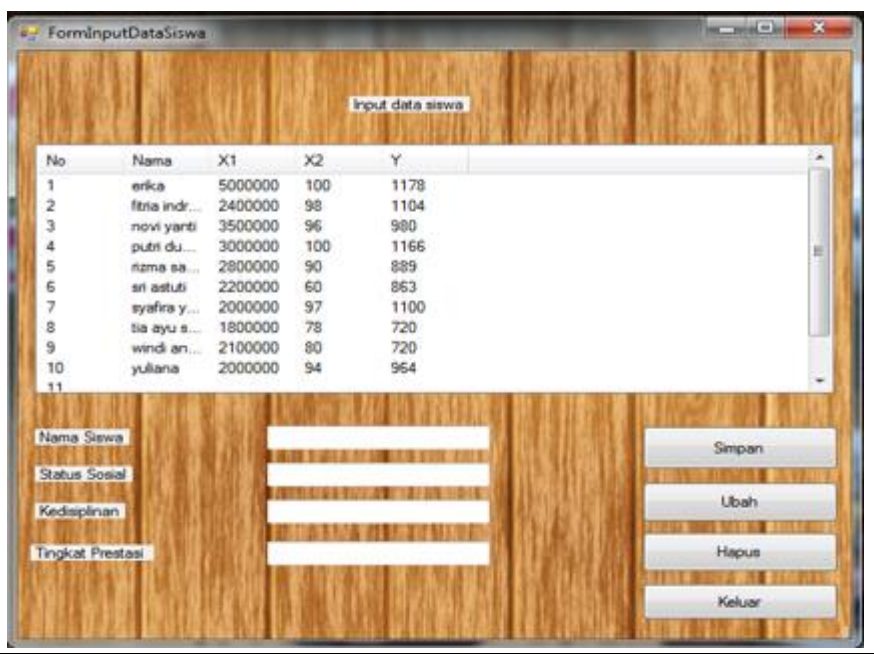


Ga mbar 4.3 Tampilan Form Input Data Siswa

Form proses merupakan tampilan yang digunakan admin untuk menghitung proses persamaan regresi dan menyimpan data tersebut.

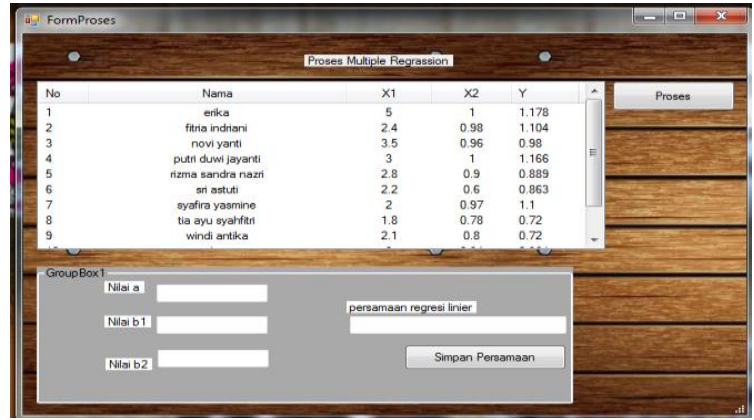

Gambar 5.4 Tampilan Form proses

Form prediksi merupakan tampilan yang digunakan admin untuk memprediksi prestasi siswa tersebut.

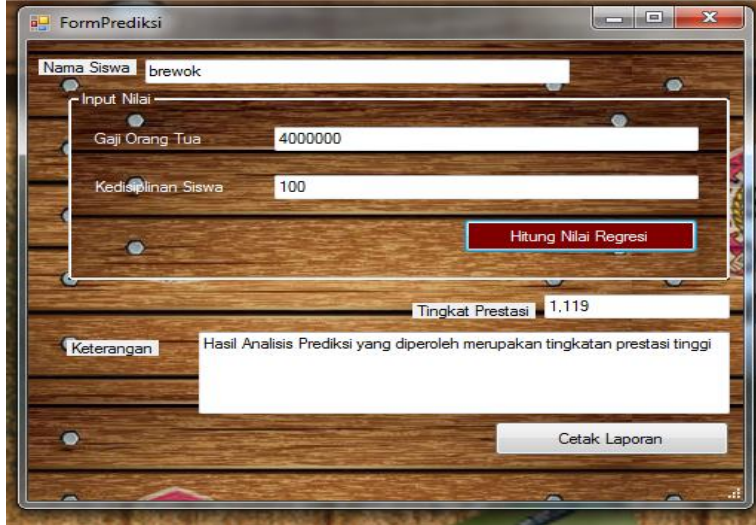

Gambar 5.5 Tampilan Form Prediksi

Adapun tampilan hasil laporan yaitu sebagai berikut :

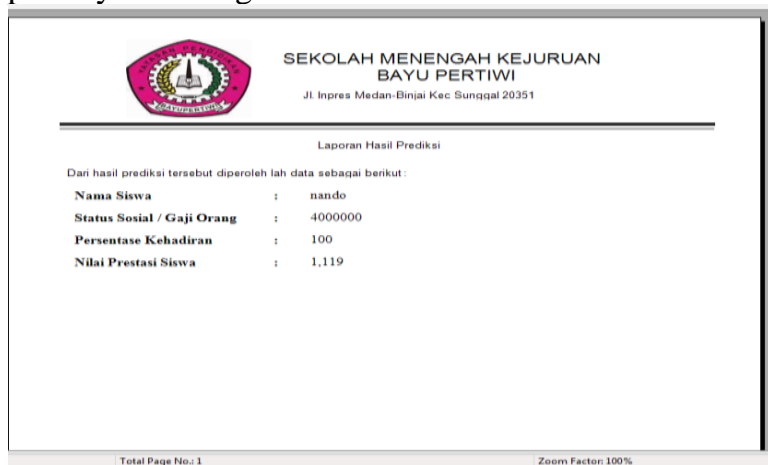

Gambar 5.6 Hasil Laporan Prediksi Prestasi Siswa

Adapun tapilan hasil laporan penginputan data siswa yaitu sebagai berikut:

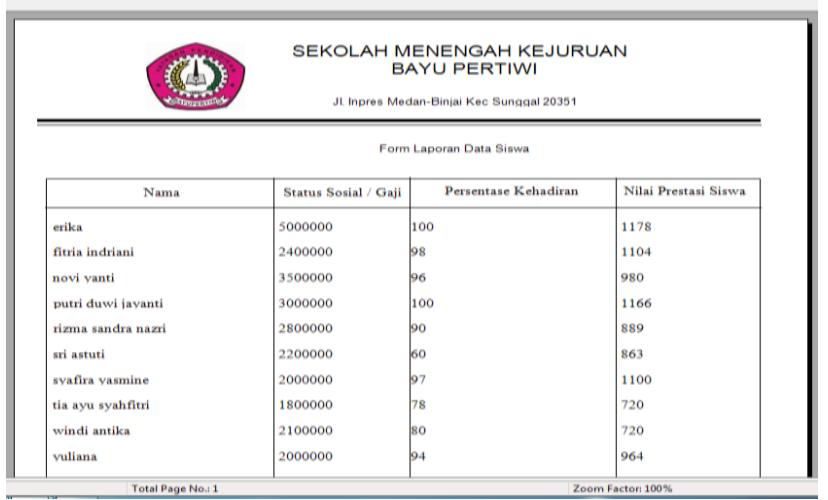


Gambar 5.7 Hasil Laporan input data siswa

\section{KESIMPULAN}

Dari hasil pembahasan pada bab sebelumnya dan pengamantan yang telah dilakukan maka dapat diambil kesimpulan diantaranya adalah sebagai berikut:

1. Penerapan metode Regresi Linier Berganda yang digunakan dalam memprediksi prestasi siswa beredasarkan status social dimana tujuanya membatu pihak sekolah untuk memprediksi hasil belajar atau prestasi di masa yang lalu untuk masa depan, dilihat dari segi kemajuan sekolah di karenakan kurangnya sarana dan prasarana siswa sehingga pihak sekolah dapat memprediksi segala kelengkapan belajar sesuai dengan prediksi siswa tersehut sehingga para siswa dapat bersaing berkompetisi dan berkompeten.

2. Aplikasi yang dibangun berbasis desktop sehingga pengguna atau pihak manajemen Sekolah SMK Bayu Pertiwi Sunggal dapat langsung melihat hasilnya melalui komputer atau laptop yang ada di sekolah tersebut dan dapat dicetak menggunakan printer.

3. Aplikasi yang telah di uji di implementasikan pada sekolah SMK Bayu Pertiwi dan digunakan oleh staff kantor pada sekolsah Smk bayu pertiwi dan digunakan sebagai acuan untuk memprediksi prestasi siswa.

\section{DAFTAR PUSTAKA}

Hendrayudi, 2011. Dasar-Dasar Pemrograman Microsoft Visual Basic 2008. Bandung: PT Sarana Tutorial Nurani Sejahtera.

J. Supranto. 2009. Statistik Teori Dan aplikasi (edisi 7). Jakarta:PT. Geloa Aksara Pratama.

Kusrini, Luthfiv taufiq emha (2009) Algoritma Data mining. Andi Yogyakarta.

Prof. Dr.Damsar Pengantar sosiologi ekonomi edisi ke dua Kencana Jakarta.

Rosa Dan M.Salahudin.2016 Rekayasa Perangkat Lunak Bandung INFORMATIKA .

Sauma, Nana, ST. 2008. Pedoman Praktikum Access 2007. Bandung: CV Yrama Widya.

\section{BIOGRAFI PENULIS}

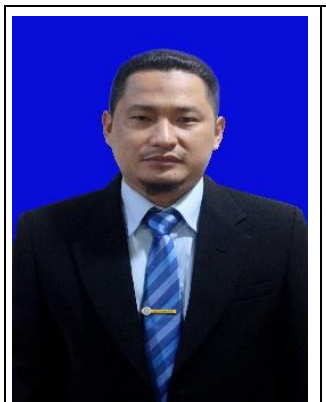

Rudi Gunawan, SE, M.Si, Pria kelahiran Belawan, 12 Januari 1981 ini saat ini memiliki jabatan Fungsional Lektro dan Jabatan Struktural Sebagai Ketua STMIK Triguna Dharma, beberapa mata kuliah diampu diantaranya statistika, metodologi penelitian. Tamat Strata 1 dan Strata 2 di Universitas Sumatera Utara (USU) Bidang Ilmu Ekonomi Pembangunan, dan saat ini sedang mengambil pendidikan Doktoral (Strata-3) Bidang Ilmu Ekonomi di Universitas Sumatera Utara (USU). 